\title{
Variation with the Cultivar on the Processing of Apples as Clear Juice
}

\author{
Vasile LAZĂR, Rodica SIMA*, Tincuța GOCAN, Alexandru MARIAN \\ University of Agricultural Sciences and Veterinary Medicine, 3-5 Manastur Street, Cluj-Napoca, 400372, \\ Romania; \\ *)Corresponding author, e-mail: rodiganea@yahoo.com
}

BulletinUASVM Horticulture 73(2) / 2016

Print ISSN 1843-5254, Electronic ISSN 1843-5394

DOI:10.15835/buasvmcn-hort:11981

\begin{abstract}
The researches done at UASVM Cluj-Napoca in the frame of Horticultural product technology Department between 2014 and 2015 assessed the behavior of five apple cultivars at processing as clear juice. The apple juice characteristics (soluble solids content, organic acids content and clarification grade) were analysed during processing of apples as clear juice and three months later, in order to determine how the initial characteristics of raw material were found again in the finished product. In order to provide the microbiological stability of juice, preservation was done with two chemical methods (sulfur dioxide $-\mathrm{SO}_{2}$ and sodium benzoate) and one physical method (pasteurization). The obtained results revealed 'Florina' cultivar, which had a processing efficiency as juice about $60 \%$, high soluble solids content, $1 \%$ acidity, good clarification grade of juice, and pasteurization as microbiological stabilization method.
\end{abstract}

Keywords: apple, characteristics, cultivar, juice

\section{INTRODUCTION}

Apples are among the most commonly consumed fruits while apple juice is one of the healthiest products, being recommended both for children and adults' consumption. According to Ravn-Haren et al., (2013) clear apple juice cannot substitute whole fruit in nutritional recommendations due to the lack of soluble as well as insoluble fibres. Even though, according to its complex chemical composition (sugars, organic acids, tannins, minerals, C vitamin), (Radu, 1985) and its low caloric content, clear apple juice has multiple favorable effects on human body, being helpful against anemia, stomach disorders, obesity, and having good antioxidant activity (Valnet, 1966; J. Oszmianski et al., 2007).

The aim of this study was to analyze five apple cultivars while processing to obtain microbiological stable clear juice. The objectives of this work were to assess how the initial characteristics (soluble solids content, organic acids content and clarification grade) were kept during preservation of apple juice and which was the best method to provide microbiological stabilization.

\section{MATERIALS AND METHODS}

The experiment was done in the frame of Horticultural product technology Department between 2014-2015. The purpose of the research was to establish the behavior of five apple cultivars when processing as clear juice and to determine how the initial characteristics of raw material were found again in the finished product.

Experimental factors were represented by five apple cultivars ('Gala', 'Red Star', 'Golden', 'Florina' and 'Idared') and three methods of juice' preservation (sulfur dioxide, sodium benzoate and pasteurization). 
Tab. 1. The characteristics of apples' raw material

\begin{tabular}{|c|c|c|c|c|c|c|c|c|c|}
\hline \multirow[b]{2}{*}{ Cultivar } & \multicolumn{3}{|c|}{ Juice' processing efficiency } & \multicolumn{3}{|c|}{ Soluble solids content } & \multicolumn{3}{|c|}{ Organic acids content } \\
\hline & $\mathrm{l} / 100 \mathrm{~kg}$ & $\begin{array}{c}\text { Difference in } \\
\text { comparison } \\
\text { with control } \\
( \pm) \\
\end{array}$ & $\begin{array}{l}\text { Difference in } \\
\text { comparison with } \\
\text { average of the } \\
\text { experiment }( \pm)\end{array}$ & $\%$ & $\begin{array}{c}\text { Difference in } \\
\text { comparison } \\
\text { with control } \\
( \pm) \\
\end{array}$ & $\begin{array}{c}\text { Difference in } \\
\text { comparison with } \\
\text { average of the } \\
\text { experiment }( \pm)\end{array}$ & $\begin{array}{l}(\% \\
\text { malic } \\
\text { acid) }\end{array}$ & $\begin{array}{c}\text { Difference in } \\
\text { comparison } \\
\text { with control } \\
( \pm) \\
\end{array}$ & $\begin{array}{l}\text { Difference in } \\
\text { comparison with } \\
\text { average of the } \\
\text { experiment }( \pm)\end{array}$ \\
\hline $\begin{array}{c}\text { 'Gala' } \\
\text { (control) }\end{array}$ & 51.66 & - & $-6.83^{0}$ & 12.60 & - & -0.29 & 0.84 & - & -0.04 \\
\hline 'Red Star' & 56.30 & 4.64 & -2.19 & 13.33 & 0.73 & 0.44 & 1.14 & $0.30^{* * *}$ & $0.26^{* *}$ \\
\hline ‘Golden’ & 67.60 & $15.94 * * *$ & $9.11^{* *}$ & 12.33 & -0.27 & -0.56 & 0.55 & $-0.29^{000}$ & $-0.33^{000}$ \\
\hline 'Florina' & 60.56 & $8.90^{*}$ & 2.07 & 14.93 & $2.04^{* *}$ & $1.16^{*}$ & 0.85 & 0.01 & 0.03 \\
\hline 'Idared' & 56.33 & 4.67 & -2.16 & 11.27 & $-1.33^{0}$ & $-1.62^{0}$ & 1.04 & $0.20 * *$ & $0.16^{*}$ \\
\hline $\begin{array}{l}\text { Average } \\
\text { of the } \\
\text { experiment } \\
\text { (control) } \\
\end{array}$ & 58.49 & - & - & 12.89 & - & - & 0.88 & - & - \\
\hline LSD $5 \%$ & & & 6.24 & & & 1.22 & & & 0.13 \\
\hline LSD $1 \%$ & & & 9.07 & & & 1.78 & & & 0.19 \\
\hline LSD $0.1 \%$ & & & 13.61 & & & 2.67 & & & 0.28 \\
\hline
\end{tabular}

By the combination of the two experimental factors, a $5 \times 3$ type of experiment with 15 experimental variants resulted. The process efficiency was determined at the processing of fruit as juice for 10 kilograms of fruit for each cultivar, in 3 replications. The characteristics of juice (soluble solids content, organic acids content of juice and clarification grade of juice) were determined at processing of apple as juice and three month after preservation. The juice was extracted with a juicer by centrifugal action and, after self-clarification ( 24 hours at $5-8^{\circ} \mathrm{C}$ ), the processing efficiency as juice with a graduated cylinder was determined. Soluble solids were determined through refractometric method and acidity by $\mathrm{NaOH}$ titration. The clarification grade of juice was visually appreciated, using a scoring system from 3 to 5 , as follows: 5 for juice with very low pulp content, well defined transparency, without impurities and suspended solids; 4 for juice with low pulp content, without impurities and with little suspended solids; 3 for juice with apparent pulp content, with semi transparency toward opaque, with little suspended solids. The obtained results were statistically analyzed.

\section{RESULTS AND DISCUSSION}

The results concerning the differences in processing efficiency as juice, soluble solids content and organic acids content of apple juice before preservation are presented in table 1 . The data were statistically analyzed as a monofactorial experiment, the cultivar being considered as experimental factor and 'Gala' cultivar and the average of the experiment as controls.

Variation with the cultivar in the processing efficiency as juice revealed statistically positive significant differences for 'Golden' (15.94 l·100 $\mathrm{kg}^{-1}$ apple) and 'Florina' (8.90 l-100 $\mathrm{kg}^{-1}$ apple) cultivars as compared with 'Gala' control and only for 'Golden' cultivar (9.11 litres' $100 \mathrm{~kg}^{-1}$ apple) as compared with average of the experiment.

The soluble solids content only for 'Florina' cultivar was with $2.04 \%$ higher as compared with 'Gala' control and with $1.16 \%$ as compared with average of the experiment.

Regarding the organic acids content of apple juice before preservation, significant increases as compared with both control variants was recorded for 'Red Star' and 'Idared' cultivars, while significant decreases as compared with both control variants were recorded for 'Golden' cultivar.

The influence of cultivar on the soluble solids content of apple juice after preservation and storage (Tab. 2) revealed 'Florina' and 'Idared' cultivars with very significant increases and 'Red Star' and 'Golden' cultivars with very significant decreases as compared with both control variants. This may be because 'Florina' and 'Idared' cultivars are rich in monosaccharides and disaccharides 
Tab. 2. The influence of cultivar on the apple juice' characteristics

\begin{tabular}{|c|c|c|c|c|c|c|c|c|c|}
\hline \multirow[b]{2}{*}{ Cultivar } & \multicolumn{3}{|c|}{ Soluble solids content } & \multicolumn{3}{|c|}{ Organic acids content } & \multicolumn{3}{|c|}{ Juice' clarification grade } \\
\hline & $\%$ & $\begin{array}{c}\text { Difference in } \\
\text { comparison } \\
\text { with control } \\
( \pm) \\
\end{array}$ & $\begin{array}{l}\text { Difference in } \\
\text { comparison with } \\
\text { average of the } \\
\text { experiment }( \pm)\end{array}$ & $\begin{array}{l}(\% \\
\text { malic } \\
\text { acid) }\end{array}$ & $\begin{array}{c}\text { Difference in } \\
\text { comparison } \\
\text { with control } \\
( \pm) \\
\end{array}$ & $\begin{array}{l}\text { Difference in } \\
\text { comparison with } \\
\text { average of the } \\
\text { experiment }( \pm)\end{array}$ & $\begin{array}{c}\text { Average } \\
\text { score }\end{array}$ & $\begin{array}{c}\text { Difference in } \\
\text { comparison } \\
\text { with control } \\
( \pm)\end{array}$ & $\begin{array}{l}\text { Difference in } \\
\text { comparison with } \\
\text { average of the } \\
\text { experiment }( \pm)\end{array}$ \\
\hline $\begin{array}{c}\text { 'Gala' } \\
\text { (control) }\end{array}$ & 12.36 & - & -0.07 & 0.89 & - & $-0.15^{00}$ & 5.11 & - & 0.37 \\
\hline 'Red Star' & 11.94 & $-0.42^{000}$ & $-0.49^{00}$ & 1.07 & $0.18^{* *}$ & 0.03 & 5.73 & $0.62^{* *}$ & $0.99^{* * *}$ \\
\hline ‘Golden' & 11.00 & $-1.36^{000}$ & $-1.43^{000}$ & 1.30 & $0.41^{* * *}$ & $0.26^{* * *}$ & 3.78 & $-1.33^{000}$ & $-0.96^{000}$ \\
\hline 'Florina' & 13.74 & $1.31^{* * *}$ & $1.31^{* * *}$ & 0.92 & -0.03 & $-0.12^{0}$ & 3.83 & $-1.28^{000}$ & $-0.91^{000}$ \\
\hline 'Idared' & 13.13 & $0.70^{* * *}$ & $0.70^{* * *}$ & 1.03 & $0.14^{* *}$ & -0.01 & 5.27 & 0.16 & $0.53^{*}$ \\
\hline $\begin{array}{l}\text { Average } \\
\text { of the } \\
\text { experiment } \\
\text { (control) }\end{array}$ & 12.43 & - & - & 1.04 & - & - & 4.74 & - & - \\
\hline LSD 5\% & & & 0.31 & & & 0.11 & & & 0.38 \\
\hline LSD1\% & & & 0.45 & & & 0.13 & & & 0.55 \\
\hline LSD $0.1 \%$ & & & 0.68 & & & 0.24 & & & 0.83 \\
\hline
\end{tabular}

Tab. 3. The influence of preservation method on the apple juice' characteristics

\begin{tabular}{|c|c|c|c|c|c|c|c|c|c|}
\hline \multirow[b]{2}{*}{$\begin{array}{l}\text { Preservation } \\
\text { method }\end{array}$} & \multicolumn{3}{|c|}{ Soluble solids content } & \multicolumn{3}{|c|}{ Organic acids content } & \multicolumn{3}{|c|}{ Juice' clarification grade } \\
\hline & $\%$ & $\begin{array}{c}\text { Difference in } \\
\text { comparison } \\
\text { with control } \\
( \pm)\end{array}$ & $\begin{array}{l}\text { Difference in } \\
\text { comparison with } \\
\text { average of the } \\
\text { experiment }( \pm)\end{array}$ & $\begin{array}{l}(\% \\
\text { malic } \\
\text { acid) }\end{array}$ & $\begin{array}{c}\text { Difference in } \\
\text { comparison } \\
\text { with control } \\
\quad( \pm)\end{array}$ & $\begin{array}{l}\text { Difference in } \\
\text { comparison with } \\
\text { average of the } \\
\text { experiment }( \pm)\end{array}$ & $\begin{array}{l}\text { Average } \\
\text { score }\end{array}$ & $\begin{array}{l}\text { Difference in } \\
\text { comparison } \\
\text { with control } \\
\qquad \pm( \pm)\end{array}$ & $\begin{array}{l}\text { Difference in } \\
\text { comparison } \\
\text { with average of } \\
\text { the experiment } \\
\qquad \pm)\end{array}$ \\
\hline $\mathrm{SO}_{2}$ (control) & 11.58 & - & $-0.85^{000}$ & 1.16 & - & $0.12^{* *}$ & 5.01 & - & $0.27^{* *}$ \\
\hline $\begin{array}{c}\text { Sodium } \\
\text { benzoate }\end{array}$ & 13.01 & $1.43^{* * *}$ & $0.58^{* * *}$ & 0.92 & $-0.24^{\circ 00}$ & $-0.12^{\circ о 0}$ & 3.55 & $-1.46^{\circ 00}$ & $-1.19^{000}$ \\
\hline Pasteurization & 12.71 & $1.13^{* * *}$ & $0.28^{*}$ & 1.04 & $-0.12^{\circ \circ}$ & 0.00 & 5.67 & $0.66^{* *}$ & $0.93^{* * *}$ \\
\hline $\begin{array}{l}\text { Average of the } \\
\text { experiment } \\
\text { (control) } \\
\end{array}$ & 12.43 & - & - & 1.04 & - & - & 4.74 & - & - \\
\hline LSD 5\% & & & 0.23 & & & 0.09 & & & 0.16 \\
\hline LSD $1 \%$ & & & 0.31 & & & 0.12 & & & 0.22 \\
\hline LSD $0.1 \%$ & & & 0.42 & & & 0.16 & & & 0.30 \\
\hline
\end{tabular}

while 'Red Star' and 'Golden' cultivars are rich in polysaccharides.

The organic acids content of the apple juice after preservation and storage (Tab. 2) was higher in the juice of 'Red Star', 'Idared' and 'Golden' cultivars as compared with 'Gala' control and only in the juice of 'Golden' cultivar as compared with average of the experiment. Statistical significant decreases of the organic acids content of the apple juice after preservation and storage revealed 'Gala' and 'Florina' cultivars but only as compared with average of the experiment. The high values of acidity could be explain through the presence of free organic acids form in 'Red Star', 'Idared' and 'Golden' cultivars while in 'Florina' and 'Gala' cultivars, with low values of total acidity, through the presence of bound organic acids form.

The unilateral influence of cultivar on the juice clarification grade (Tab. 2) positively revealed the 'Red Star' cultivar if the result was compare with 'Gala' control and 'Red Star' and 'Idared' cultivars if the results were compared with average of the experiment. 'Red Star' cultivar has a fine consistency and it is low in pectic 
Tab. 4. Variation with interaction of cultivars and preservation method on apple juice' characteristics

\begin{tabular}{|c|c|c|c|c|c|c|c|c|c|c|}
\hline \multirow[b]{2}{*}{ Cultivar } & \multirow[b]{2}{*}{$\begin{array}{l}\text { Preservation } \\
\text { method }\end{array}$} & \multicolumn{3}{|c|}{ Soluble solids content } & \multicolumn{3}{|c|}{ Organic acids content } & \multicolumn{3}{|c|}{ Juice' clarification grade } \\
\hline & & $\%$ & $\begin{array}{l}\text { Difference } \\
\text { in } \\
\text { comparison } \\
\text { with control } \\
\quad \pm( \pm)\end{array}$ & $\begin{array}{l}\text { Difference in } \\
\text { comparison } \\
\text { with average of } \\
\text { the experiment } \\
\qquad \pm)\end{array}$ & $\begin{array}{c}(\% \\
\text { malic } \\
\text { acid) }\end{array}$ & $\begin{array}{c}\text { Difference } \\
\text { in } \\
\text { comparison } \\
\text { with control } \\
\quad( \pm)\end{array}$ & $\begin{array}{l}\text { Difference in } \\
\text { comparison } \\
\text { with average of } \\
\text { the experiment } \\
\qquad \pm)\end{array}$ & $\begin{array}{c}\text { Average } \\
\text { score }\end{array}$ & $\begin{array}{l}\text { Difference } \\
\text { in } \\
\text { comparison } \\
\text { with } \\
\text { control }( \pm) \\
\end{array}$ & $\begin{array}{c}\text { Difference in } \\
\text { comparison } \\
\text { with average } \\
\text { of the } \\
\text { experiment } \\
( \pm)\end{array}$ \\
\hline \multirow{3}{*}{$\begin{array}{c}\text { 'Gala' } \\
\text { (control) }\end{array}$} & $\mathrm{SO}_{2}$ (control) & 10.87 & - & $-1.58^{000}$ & 1.07 & - & 0.03 & 5.83 & - & $1.09^{* * *}$ \\
\hline & $\begin{array}{c}\text { Sodium } \\
\text { benzoate }\end{array}$ & 13.60 & $2.73^{* * *}$ & $1.15^{* * *}$ & 0.75 & $-0.32^{\circ o}$ & $-0.29^{\circ}$ & 3.73 & $-2.10^{\circ 00}$ & $-1.01^{000}$ \\
\hline & Pasteurization & 12.60 & $1.73^{* * *}$ & 0.15 & 0.84 & $-0.23^{\circ}$ & $-0.20^{\circ}$ & 5.77 & -0.06 & $1.03^{* * *}$ \\
\hline \multirow{3}{*}{$\begin{array}{l}\text { 'Red } \\
\text { Star' }\end{array}$} & $\mathrm{SO}_{2}$ & 12.13 & $1.26^{* * *}$ & -0.32 & 1.13 & 0.06 & 0.09 & 5.90 & 0.07 & $1.16^{* * *}$ \\
\hline & $\begin{array}{c}\text { Sodium } \\
\text { benzoate }\end{array}$ & 12.47 & $1.60^{* * *}$ & 0.02 & 0.96 & -0.11 & -0.08 & 5.53 & -0.30 & $0.79^{* * *}$ \\
\hline & Pasteurization & 11.23 & 0.36 & $-1.22^{\text {ооо }}$ & 1.11 & 0.04 & 0.07 & 5.77 & -0.06 & $1.03^{* * *}$ \\
\hline \multirow{3}{*}{ 'Golden' } & $\mathrm{SO}_{2}$ & 11.07 & 0.20 & $-1.38^{\circ 00}$ & 1.57 & $0.50^{* * *}$ & $0.53^{* * *}$ & 3.83 & $-2.00^{\circ 00}$ & $-0.91^{000}$ \\
\hline & $\begin{array}{c}\text { Sodium } \\
\text { benzoate }\end{array}$ & 9.53 & $-1.34^{\circ 00}$ & $-2.92^{\circ 00}$ & 0.97 & -0.10 & -0.07 & 1.83 & $-4.00^{\circ 00}$ & $-2.91^{\circ 00}$ \\
\hline & Pasteurization & 12.40 & $1.53^{* * *}$ & -0.05 & 1.34 & $0.27^{* *}$ & $0.30^{* *}$ & 5.67 & -0.16 & $0.93^{* * *}$ \\
\hline \multirow{3}{*}{ 'Florina' } & $\mathrm{SO}_{2}$ & 11.57 & $0.70^{* *}$ & $-0.88^{\circ o}$ & 0.94 & -0.13 & -0.10 & 3.83 & $-2.00^{\circ 00}$ & $-0.91^{000}$ \\
\hline & $\begin{array}{c}\text { Sodium } \\
\text { benzoate }\end{array}$ & 15.27 & $4.40^{* * *}$ & $2.82^{* * *}$ & 0.88 & $-0.19^{\circ}$ & -0.16 & 1.77 & $-4.06^{000}$ & $-2.97^{\circ 00}$ \\
\hline & Pasteurization & 14.60 & $3.73^{* * *}$ & $2.15^{* * *}$ & 0.92 & -0.15 & -0.12 & 5.90 & 0.07 & $1.16^{* * *}$ \\
\hline \multirow{3}{*}{ 'Idared' } & $\mathrm{SO}_{2}$ & 12.47 & $1.60^{* * *}$ & 0.02 & 1.08 & 0.01 & 0.04 & 5.63 & -0.20 & $0.89^{* * *}$ \\
\hline & $\begin{array}{c}\text { Sodium } \\
\text { benzoate }\end{array}$ & 14.20 & $3.33^{* * *}$ & $1.75^{* * *}$ & 1.03 & -0.04 & -0.01 & 4.90 & $-0.93^{\circ 00}$ & 0.16 \\
\hline & Pasteurization & 12.73 & $1.86^{* * *}$ & 0.28 & 0.99 & -0.08 & -0.05 & 5.27 & $-0.56^{\circ 0}$ & $0.53^{* *}$ \\
\hline \multicolumn{2}{|c|}{$\begin{array}{c}\text { Average of the } \\
\text { experiment (control) }\end{array}$} & 12.45 & - & - & 1.04 & - & - & 4.74 & - & - \\
\hline \multicolumn{2}{|l|}{ LSD 5\% } & & \multicolumn{2}{|r|}{0.50} & \multicolumn{3}{|r|}{0.19} & & \multicolumn{2}{|r|}{0.36} \\
\hline \multirow{2}{*}{\multicolumn{2}{|c|}{$\begin{array}{l}\text { LSD } 1 \% \\
\text { LSD } 0.1 \%\end{array}$}} & & \multirow{2}{*}{\multicolumn{2}{|c|}{$\begin{array}{l}0.69 \\
0.93\end{array}$}} & \multirow{2}{*}{\multicolumn{3}{|c|}{$\begin{array}{l}0.26 \\
0.35\end{array}$}} & & \multicolumn{2}{|r|}{0.49} \\
\hline & & & & & & & & & \multicolumn{2}{|r|}{0.66} \\
\hline
\end{tabular}

substances, characteristics that ensure it a better clarification grade than other studied cultivars. With very significant decreases regarding the same parameter as compared with both control variants, 'Golden' and 'Florina' cultivars were remarked.

Regarding the unilateral influence of preservation method on the soluble solids content of apple juice after storage, (Tab. 3), statistically significant increases were obtained with sodium benzoate and pasteurization as compared with both control variants - sulfur dioxide and average of the experiment, respectively.

Sulfur dioxide preservation method determined statistically significant increase of organic acids content of juice as compared with average of the experiment (Tab. 3). Sodium benzoate method of preservation determined statistically significant decreases of organic acids content of apple juice as compared with both experimental factors, while pasteurization as compared with sulfur dioxide control.

Sodium benzoate preservation method negatively influenced the clarification grade of juice after storage as compared with both control variants (Tab. 3). A positive influence on the clarification grade of apple juice had sulfur dioxide method as compared with average of the experiment and pasteurization method as compared with both control variants.

The combined influence of cultivar and preservation method on the soluble solids 
content of the apple juice after preservation and storage (Tab. 4) revealed that this parameter was mainly influenced by cultivar. Thus, 'Idared' and 'Florina' cultivars recorded statistically significant increases of juice' soluble solids content regardless the preservation method as compared with 'Gala' preserved by Sulfur dioxide - control. Sodium benzoate preservation method determined statistically very significant increases of soluble solids in the apple juice of 'Gala' and 'Red Star' cultivars, while pasteurization in the juice of 'Gala' and 'Golden' cultivars as compared with the same control. When comparison was done with the average of the experiment sodium benzoate method of preservation revealed statistically very significant juice' soluble solids content increases in three of the studied cultivars ('Gala', 'Florina' and 'Idared').

The influence of both experimental factors on the organic acids content of apple juice after storage revealed statistically significant increases only in 'Golden' cultivar preserved by sodium benzoate and pasteurization as compared with both control variants (Tab. 4).

The influence of experimental factors' interaction on the clarification grade of juice emphasized pasteurization method of juice' preservation which determined statistically significant increases of juice clarification as compared with average of the experiment, regardless the studied cultivar (Tab. 4). Very significant increases of the clarification grade of juice were revealed by sulfur dioxide method of preservation for 'Gala', 'Red Star' and 'Idared' cultivars as compared with average of the experiment.

\section{CONCLUSIONS}

Analyzing the results of the research concerning the behavior of five apple cultivars at processing as clear juice and how the initial characteristics of raw material were found again in the finished product, the following conclusion can be mentioned:

- the best processing efficiency as juice was revealed at 'Golden' (67.60 l.100 $\left.\mathrm{kg}^{-1}\right)$ and 'Florina' $\left(60.56 \mathrm{l} \cdot 100 \mathrm{~kg}^{-1}\right)$ cultivars;
- concerning the juice' characteristics before preservation and storage, the highest soluble solids content at 'Florina' (14.19\%) while the highest acidity at 'Gala' (1.40\% malic acid) were recorded;

- variation with cultivar of the three analyzed characteristics of the apple juice after preservation and storage revealed 'Florina' and 'Idared' cultivars for soluble solids content, 'Red Star', 'Idared' and 'Golden' cultivars for juice acidity and 'Red Star' cultivar for the best clarification grade;

- the three analyzed characteristics of apple juice varied under the influence of preservation method. Thus, the soluble solids content was positively influenced by preservation with sodium benzoate and pasteurization, juice acidity was higher at sulfur dioxide preservation while clarification grade was better at variants preserved with sodium dioxide and pasteurization;

'Florina', among the apple studied cultivars, represents a good recommendation for producing of a clear juice due to its high processing efficiency as juice (60 l.100 kg-1), the highest soluble solids content and good acidity (1\%) while pasteurization, among the studied preservation methods, provided the best microbiological stability.

\section{REFERENCES}

1. Oszmianski J, Wolnina M, Wojdylo A, Wawer I (2007). Comparative study of polyphenolic content and antiradical activity of cloudy and clear apple juice. J Sci Food Agr 87(4):573-579.

2. Radu IF (1985). Tratat de tehnologia fructelor şi legumelor. Ed. Scrisul Românesc Craiova.

3. Ravn-Haren Gitte, Dragsted LO, Buch-Andersen T, Eva Jensen, Runa Jensen, Maria Nemeth-Balogh, Brigita Paulovicsova, Anders Bergstrom, Andrea Wilcks, Licht TR, Markowski J, Susanne Bugel (2013). Intake of whole apples or clear apple juice has contrasting effects on plasma lipids in healthy volunteers. Eur J Nutr 52:18751889.

4. Valnet I (1996). Tratarea bolilor prin legume, fructe și cereale. Ed. Ceres București. 